\title{
Effect of letrozole on masculinization of Siamese fighting fish (Betta splendens)
}

\author{
Milind B. Katare*1, N. Basavaraja ${ }^{1}$, Harshavardhan D. Joshi ${ }^{2}$ and Chirom Archana ${ }^{2}$ \\ ${ }^{1}$ Department of Aquaculture, Karnataka Veterinary, Animal and Fisheries Sciences University, College of Fisheies, \\ Mangalore- 575002 (Karnataka), INDIA \\ ${ }^{2}$ Aquaculture Division, Central Institute of Fisheries Education, Andheri (West), Mumbai-400061 (Maharashtra), \\ INDIA \\ *Corresponding author. E-mail: mcofsn@gmail.com
}

Received: January 22, 2015; Revised received: April 30, 2015; Accepted: May 27, 2015

\begin{abstract}
The aim of this study was to evaluate the effect of letrozole (a non-steroidal aromatase inhibitor) on masculinization of Siamese fighting fish (Betta splendens). Different doses of letrozole 50, 100, 150 and 200 ppm $(\mathrm{mg} / \mathrm{kg}$ feed) were incorporated into diet and fed for periods of 30, 40 or 50 days. Immersion treatment of letrozole at selected doses $(250,500,750$ and 1,000 $\mathrm{g} / \mathrm{l})$ for $3 \mathrm{~h}$ each on third, fifth and eighth day-post-hatching (dph) (Trial 1) and fourth, sixth and eighth dph (Trial 2) was given. The oral administration of letrozole for 30, 40 or 50 days did not have any significant effect on the sex ratio of $B$. splendens. The immersion treatment of letrozole induced $100 \%$ masculinization at 500 and $1000 \mu \mathrm{g} / \mathrm{l}$ in trial 1, while it yielded only 66.66 and $90 \%$ male population at 500 and 1000 $\mu \mathrm{g} / \mathrm{l}$ in Trial 2. The dietary administration of letrozole for 30 and 50 days caused tail deformities and/or rudimentary and absence of dorsal fin. The progeny testing of males from letrozole treated (both oral and immersion) groups indicate that the sex ratio of progenies of each of the males tested did not differ significantly from that of control, indicating that all those males carried $X Y$ genotype. Letrozole treatments suppressed ovarian development (atretic oocytes were common). However, the testicular development was unaffected. The study revealed that immersion treatment of letrozole was more effective in inducing masculinization of $B$. splendens than the oral administration of letrozole.
\end{abstract}

Keywords: Aromatase inhibitor, Deformity, Fighting fish, Masculinization, Histology

\section{INTRODUCTION}

The quantity of ornamental fish traded worldwide has increased steadily over the years. The Siamese fighting fish (Betta splendens), also known as the Betta and simply as the fighter, is a popular species of fresh water aquarium fish. It has been affectionately nicknamed "The Jewel of the orient" due to large flowing fins and a wide range of colors. The male Betta will flare his gills, twist his body and spread his fins during mating. Female is duller in color and smaller in size. Males build bubble nests of various sizes and thickness at the surface of water. Males are in greater demand and fetch a much better price than females. Functional sex of an animal is reversed by direct treatment with estrogens or androgens during the period of sex differentiation in the early stage of gonad genesis. Fish breeders are able to produce either males or females separately depending upon the demand for monosex fish.

Earlier studies were extended to $B$. splendens to produce a monosex male population (Jessy and Varghese, 1988; Pandian and Sheela, 1995; Kavumpurath and Pandian, 1994; Kirankumar and Pandian, 2002; Balsubramani and Pandian, 2008; Kipouros et al.,
2011). Feeding $B$. splendens with a diet containing $17 \alpha$ -methyltestosterone (17 $\alpha-\mathrm{MT})$ at doses of $80-140 \mathrm{ppm}$ resulted in the production of $80,86.9,87.5$ and $91.3 \%$ males, respectively (Jessy and Varghese, 1988). A $100 \%$ masculinization was achieved when Betta was fed at doses 8, 15, 60 and $90 \mathrm{mg} / \mathrm{kg}$ 19-nor -ethyltestosterone, 17 $\alpha$-MT, 11-ketotestosterone and androstenedione, respectively (Kavumpurath and Pandian, 1994).

In recent years, aromatase inhibitors find increasing application for sex control in fish. Aromatase is a cytochrome P450 enzyme complex that is required for biosynthesis of estrogens that converts testosterone to estradiol and androstenedione to estrone. Blocking P450arom activity using chemicals is common and they are known as aromatase inhibitors (AI), leading to a decrease in the production of estrogen (Steele et al., 1987). AIs have been used in the treatment of breast and ovarian cancer in postmenopausal women (Howell et al., 2005) and in studies of sex change in a wide range of teleost fish, e.g., tilapia (Kwon et al., 2000; Afonso et al., 2001; Das et al., 2012), salmon (Piferrer et al., 1994), Japanese flounder (Kitano et al., 2000), zebrafish (Fenske and segner, 2004 and guppy (Basavaraja et al., 2012). It was possible to masculinize genetic females $(\mathrm{XX})$ to phenotypic males $(\mathrm{XX})$ 
through dietary administration of a common aromatase inhibitor, femura (chemical name: letrozole) to the java tilapia (Oreochromism ossambicus), wherein $100 \%$ male population could be produced by treating the fry at 100-200 ppm diet for 30 days (Das et al., 2012), letrozole in combination with $17 \alpha-\mathrm{MT}$ also induced the production of $100 \%$ male tilapia population; letrozole administration did not indicate any adverse effect on growth, survival and proximate composition of the tilapia. Letrozole at 100 ppm produced 92, 93 and 97\% male guppy when treated for 30, 40 and 50 days (Basavaraja et al., 2012). Since the use of steroids evokes public concern, one alternative strategy would be the application of non-steroidal drugs like letrozole. Hence, the study was conducted to produce an all-male progeny using letrozole and also to test its effect on morphology and gonadal development in Siamese fighting fish, $B$. splendens.

\section{MATERIALS AND METHODS}

The present study was conducted at fish farm of the College of Fisheries, Mangalore.

Incorporation of letrozole: The commercially available fry feed (Nutri feed) of Godrej AgrovetVijaywada, Andhra Pradesh was used as a basal diet for the administration of letrozole. Required quantity of feed (100 g) was weighed, powdered using a grinder and packed in air tight polythene bags and stored at $4^{\circ} \mathrm{C}$. The letrozole tablets (common name: Femura, trade name: Letroz, Sun-Pharmaceutical, Gujarat, India), molecular formula $\left(\mathrm{C}_{14} \mathrm{H}_{13} \mathrm{~N}_{3}\right.$.HCL $)$ and chemical name 4-(5, 6, 7, 8-tetra hydroimidazole $(1,5-a)$ pyrdin-yl benzonitrilemonohydrochloride) procured from a local dealer was used for incorporation into feed. The required quantity of the powdered basal feed (100 g) was taken in plastic tray and used as the letrozole carrier feed prepared using alcohol evaporation method (Guerrero, 1975). The required quantity of letrozole i.e. 50, 100, 150 and $200 \mathrm{mg}$ (weighed accurately using an electrical balance) was dissolved in $50 \mathrm{ml}$ of $95 \%$ ethanol and the AI-dissolved ethanol was sprayed on feed uniformly using a chromatogram column sprayer. The feed was mixed thoroughly with a glass rod to ensure proper mixing of letrozole into the feed. The letrozole incorporated diet was dried at room temperature to allow the ethanol to evaporate. The control diet was prepared in the same manner using ethanol only. After drying the respective feeds were packed in air tight polythene bags and stored in a refrigerator at $4^{\circ} \mathrm{C}$.

Development of brood-stock and fry production: Betta stocks obtained from local aquarists and maintained at the College farm were used to develop brood fish. The same was raised by feeding daily twice with mosquito larvae and zooplankton. The gravid female and male Betta (identified based on their external characteristics) were selected for fry production. The female and male brooders (1:1) were held in an aquarium $(2 \times 1 \times 1.5 \mathrm{ft})$ for breeding. In about one or two days of their release in the aquarium, breeding took place wherein the eggs were released in batches and fertilized. The resultant fry were used for experimentation. The aquaria were aerated using an air blower. Before stocking the fry, the aquaria $(2 \times 1 \times 1.5 \mathrm{ft})$ were disinfected with a solution of potassium permanganate $\left(\mathrm{KMnO}_{4}\right)$ at $5 \mathrm{ppm}$, cleaned, dried and filled with fresh filtered water.

Letrozole treatment to fry: Three or four-day-old Betta fry were divided into five groups of 30 to 50 each and designated as $T_{0}, T_{1}, T_{2}, T_{3}$ and $T_{4}$ for $0,50,100,150$ and $200 \mathrm{ppm}$ letrozole, respectively and fed ad libitum twice daily for periods 30,40 or 50 days. The immersion treatment of letrozole was carried out at concentrations of 250, 500, 750 and $1000 \mu \mathrm{g} / \mathrm{l}$ water. Randomly selected fry were subjected to discrete immersion treatment of letrozole for $3 \mathrm{~h}$ each on third, fifth and eighth days of post hatching (dph) or for 3 hours each on fourth, sixth and eighth dph. Stock solution of letrozole was prepared in absolute alcohol. A control group was maintained without letrozole. About $50 \%$ water was exchanged once every four days during treatment period to remove excreta, uneaten food and the accumulated metabolites of letrozole. All the tanks were aerated using an air blower.

Fry rearing: Cement tanks $(2.5 \times 2.5 \times 3 \mathrm{ft})$ were used for post-treatment rearing of fry from respective groups and reared for a period of 90 days. Before stocking of fry, the cement tanks were drained, dried, filled with fresh water and manured with chicken manure at $200 \mathrm{~g} / \mathrm{m}^{2}$. During post- treatment rearing, the fry were fed with sieved zooplankton till maturity.

Evaluation of letrozole treatment: On termination of the experiments, all the surviving fish were harvested and counted. The phenotypic sex of the treated and control fish was determined by the secondary sexual characters, such as the shape of the belly, body coloration and finnage.

Progeny testing : In order to confirm the efficiency of sex conversion, progeny testing was carried out, for which sex reversed males from treated group were mated with normal females in glass tanks $(2 \times 1 \times 1.5 \mathrm{ft})$ at a ratio of $1: 1(\mathrm{M}: \mathrm{F})$; the resultant progeny was reared in cement tank $(2.5 \times 2.5 \times 3 \mathrm{ft})$ for three months and during this period the fry were fed with control feed at $50 \%$ of their body weight. Upon maturity, the fishes were sexed by means of secondary sexual characters like colour, size, shape of the belly and finnage.

Histology of gonads: The gonads of control and treatment groups were collected, preserved, fixed, embedded, section taken, stained (Gray, 1964) and sections were observed under a microscope (Olympus) and photographed.

Statistical analysis: The Chi-square test was employed to test the equality of sex ratio among different groups.

\section{RESULTS}

Sex ratio: The results of the oral administration of letrozole for 30,40 or 50 days are presented in tables 1 -3 . The survival ranged between 14 and $32.5 \%$ during 
letrozole treatment period. Among the letrozole treated groups, the percentage of males remained unaffected, indicating that the letrozole administration (oral) does not cause masculinization at the tested doses (Tables 1 -3). On the other hand, a higher percentage of females were found in majority of the groups treated with letrozole. The survival during post-treatment rearing varied between 41.66 and $100 \%$ (Tables 1-3).

Tail deformity and fin abnormality: Tail deformities and fin deformities were often observed in the groups treated with letrozole for 40 and 50 days and the details are presented in fig. 1 and table 4. Various patterns of skeletal deformities like bent vertebral column and tail were observed. The absence of dorsal fin or rudimentary dorsal fin was frequently observed in the letrozole-fed fish. It was observed that as the dose increased, the percentage of deformity and abnormality also increased. The highest deformity $(100 \%)$ was observed in the group treated with letrozole at $200 \mathrm{ppm}$ for 40 days. The control did not exhibit any deformities (Fig. 1 and Table 4).

Immersion treatment: The results of the immersion treatment of letrozole are presented in tables 5 and 6 . The survival of fry during treatment period ranged between 37.5 and $70 \%$, while it varied between 27.8 and $62.5 \%$ during post-treatment period (Tables 5 and $6)$. Among treated groups, the highest percentage of males $(100 \%)$ was obtained in the group treated with letrozole at 500 and $1000 \mu \mathrm{g} / \mathrm{l}$ (Trial 1), whereas the highest percentage of males $(90 \%)$ was observed at $1000 \mu \mathrm{g} / \mathrm{l}$ (Trial 2).

Progeny testing of letrozole treated fish: Table 7 shows the results of progeny testing of males that received letrozole incorporated feed and immersion treatment of letrozole. The survival of progenies of the oral trial ranged between 37.68 and $40 \%$. All the three males (from $150 \mathrm{ppm}$ group) when mated with normal female at $1: 1$, produced almost normal sex ratios (42.30, 47.82, 50\% males and 57.70, 52.18, 50\% females, respectively), indicating all the males had XY -genotype. The Control group yielded $58.34 \%$ males and $41.66 \%$ females. The sex ratio was not significantly different $(\mathrm{P}>0.05)$ in each of the progeny tested groups, when compared with Control (Table 7). The survival of different progenies of the immersion trial ranged between 21.73 and $41.53 \%$. Progenies from $500 \mu \mathrm{g} / \mathrm{l}$ group had 62.07, 46.66 and $40 \%$ males and 37.93, 53.34 and $60 \%$ females, respec-

Table 1. Number of fry stocked and recovered, sex composition and survival of B. splendens fed with varying doses of letrozole for 30 days.

\begin{tabular}{lccccccccc}
\hline \multicolumn{4}{c}{ Treatment period } & \multicolumn{7}{c}{ Post- treatment period } \\
\hline $\begin{array}{l}\text { Treat- } \\
\text { ment }\end{array}$ & $\begin{array}{c}\text { No. of } \\
\text { fry } \\
\text { (Initial) }\end{array}$ & $\begin{array}{c}\text { No. of } \\
\text { fry } \\
\text { (Final) }\end{array}$ & $\begin{array}{c}\text { Survival } \\
(\%)\end{array}$ & $\begin{array}{c}\text { No. of fish } \\
\text { recovered }\end{array}$ & Male & Female & $\begin{array}{c}\text { Survival } \\
(\%)\end{array}$ & $\begin{array}{c}\text { Sex } \\
\text { ratio } \\
\text { (M:F) }\end{array}$ & $\begin{array}{c}\text { Chi-square } \\
\text { value (against } \\
\mathbf{1 : 1} \text { sex ratio) }\end{array}$ \\
\hline Control & 40 & 10 & 25 & 7 & $1(14.29)$ & $6(85.71)$ & 70 & $1: 6$ & 3.56 \\
$50 \mathrm{ppm}$ & 40 & 13 & 32.5 & 7 & $2(28.58)$ & $5(71.42)$ & 53.84 & $1: 2.5$ & 1.28 \\
$100 \mathrm{ppm}$ & 40 & 11 & 27.5 & 6 & $3(50)$ & $3(50)$ & 54.54 & $1: 1$ & 0 \\
$150 \mathrm{ppm}$ & 40 & 11 & 27.5 & 7 & $3(42.85)$ & $4(57.15)$ & 63.63 & $1: 1.3$ & 0.14 \\
$200 \mathrm{ppm}$ & 40 & 9 & 22.5 & 5 & $2(40)$ & $3(60)$ & 55.55 & $1: 1.5$ & 0.2
\end{tabular}

Sex composition figures given in parentheses are expressed as a percentage of total number of fish. Statistically not significant at $5 \%$ level from the expected 1:1 sex ratio; M: Male, F: Female

Table 2. Number of fry stocked and recovered, sex composition and survival of B. splendens fed with varying doses of letrozole for 40 days.

\begin{tabular}{lccccccccc}
\hline & \multicolumn{3}{c}{ Treatment period } & \multicolumn{5}{c}{ Post- treatment period } \\
\hline $\begin{array}{l}\text { Treat- } \\
\text { ment }\end{array}$ & $\begin{array}{c}\text { No. of } \\
\text { fry } \\
\text { (Initial) }\end{array}$ & $\begin{array}{c}\text { No. of } \\
\text { fry } \\
\text { (Final) }\end{array}$ & $\begin{array}{c}\text { Survival } \\
(\%)\end{array}$ & $\begin{array}{c}\text { No. of fish } \\
\text { recovered }\end{array}$ & Male & Female & $\begin{array}{c}\text { Survival } \\
(\%)\end{array}$ & $\begin{array}{c}\text { Sex } \\
\text { ratio } \\
\text { (M:F) }\end{array}$ & $\begin{array}{c}\text { Chi-square } \\
\text { value (against } \\
\text { 1:1 sex ratio) }\end{array}$ \\
\hline Control & 50 & 10 & 20 & 7 & $2(28.58)$ & $5(71.42)$ & 70 & $1: 2.5$ & 1.28 \\
$50 \mathrm{ppm}$ & 50 & 13 & 26 & 8 & $4(50)$ & $4(50)$ & 61.53 & $1: 1$ & 0 \\
$100 \mathrm{ppm}$ & 50 & 14 & 28 & 9 & $3(33.34)$ & $6(66.66)$ & 64.28 & $1: 2$ & 1 \\
$150 \mathrm{ppm}$ & 50 & 12 & 24 & 5 & $2(40)$ & $3(60)$ & 41.66 & $1: 1.5$ & 0.2 \\
$200 \mathrm{ppm}$ & 50 & 7 & 14 & 7 & $2(28.58)$ & $5(71.42)$ & 100 & $1: 2.5$ & 1.28 \\
\hline
\end{tabular}

Sex composition figures given in parentheses are expressed as a percentage of total number of fish. Statistically not significant at $5 \%$ level from the expected 1:1 sex ratio; M: Male, F: Female 


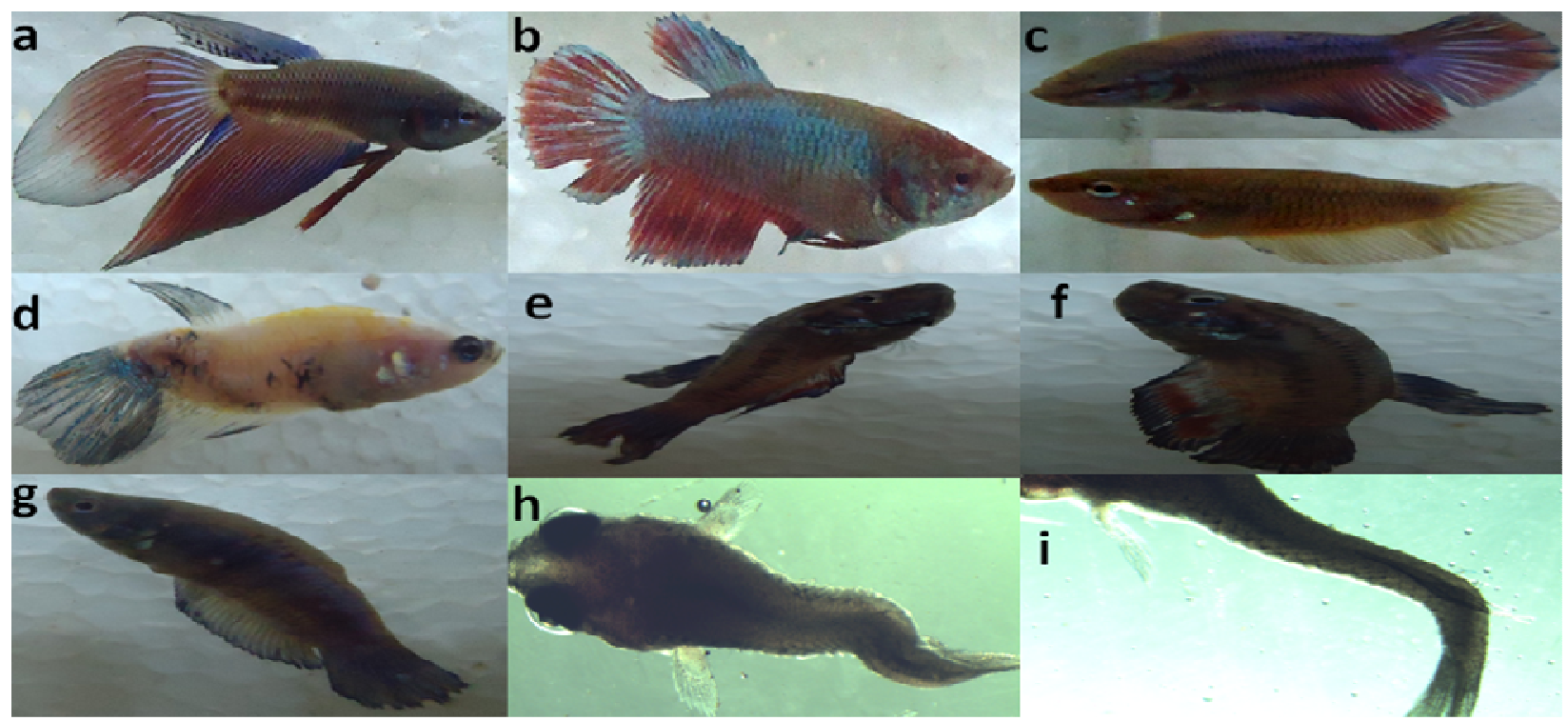

Fig. 1. Effect of untreated and letrozole-treated diet on the morphological characteristics of Betta. (a) Normal male, (b) Normal female, (c) Females without dorsal fin, (d) Male with a rudimentary dorsal fin and bent caudal region, (e) Male with rudimentary dorsal fin, anal fin and deformed body, $(f)$ Male with a curved body, rudimentary dorsal fin, showing vertical movement, $(g)$ Male without dorsal fin and abnormal tail, showing slanting movement, $(h)$ A 40-day treated fry with an abnormal head region and a bent tail, (i) A 50-day letrozole treated fry showing an elongated and curved tail.

Table 3. Number of fry stocked and recovered, sex composition and survival of B. splendens fed varying doses of letrozole for 50 days.

\begin{tabular}{lccccccccc}
\hline & \multicolumn{3}{c}{ Treatment period } & \multicolumn{7}{c}{ Post- treatment period } \\
\hline $\begin{array}{l}\text { Treat- } \\
\text { ment }\end{array}$ & $\begin{array}{c}\text { No. of } \\
\text { fry } \\
\text { (Initial) }\end{array}$ & $\begin{array}{c}\text { No. of } \\
\text { fry } \\
\text { (Final) }\end{array}$ & $\begin{array}{c}\text { Survival } \\
(\%)\end{array}$ & $\begin{array}{c}\text { No. of } \\
\text { fish re- } \\
\text { covered }\end{array}$ & Male & Female & $\begin{array}{c}\text { Survival } \\
(\%)\end{array}$ & $\begin{array}{c}\text { Sex } \\
\text { ratio } \\
(\text { M:F) }\end{array}$ & $\begin{array}{c}\text { Chi-square } \\
\text { value ( against } \\
\mathbf{1 : 1} \text { sex ratio) }\end{array}$ \\
\hline Control & 50 & 10 & 20 & 8 & $3(37.50)$ & $5(62.50)$ & 80 & $1: 1.6$ & 0.5 \\
$50 \mathrm{ppm}$ & 50 & 10 & 20 & 7 & $3(42.85)$ & $4(57.15)$ & 70 & $1: 1.3$ & 0.14 \\
$100 \mathrm{ppm}$ & 50 & 12 & 24 & 10 & $3(30)$ & $7(70)$ & 83.33 & $1: 2.3$ & 1.6 \\
$150 \mathrm{ppm}$ & 50 & 11 & 22 & 9 & $4(44.44)$ & $5(55.55)$ & 81.81 & $1: 1.2$ & 0.11 \\
$200 \mathrm{ppm}$ & 50 & 8 & 16 & 8 & $3(37.50)$ & $5(62.50)$ & 100 & $1: 1.6$ & 0.5
\end{tabular}

Sex composition figures given in parentheses are expressed as a percentage of total number of fish. Statistically not significant at $5 \%$ level from the expected 1:1 sex ratio; M: Male, F: Female

tively, while the progenies from $1000 \mu \mathrm{g} / \mathrm{l}$ group consisted of $64.29,30.44$ and $33.34 \%$ males and 35.71 , 69.56 and $66.66 \%$ females, respectively. The two Control groups had 48.64 and $45.45 \%$ males and 51.36 and $54.55 \%$

females, respectively. The sex ratio was not significantly ( $\mathrm{P}>0.05$ ) different (Table 7).

Histology of gonads: The results of the histological examination of the ovary of fish fed with letrozole -incorporated diet are presented in fig. 2. The ovaries of Control fish showed different stages of oogenesis like perinucleolar stage, primary oocyte growth, early vitellogenesis etc. The histology of letrozole -treated fish showed a slight suppression of ovary with atretic or degenerating oocytes and increased vacuolar area (Fig. 2). The results of the histological examination of the testis of fish fed with letrozole are presented in fig. 3. No significant difference was found in the spermatogenesis of both Control and letrozole treated fish. The histology of testis revealed the presence of normal spermatogonia, spermatocytes, spermatids and spermatozoa (Fig. 3).

\section{DISCUSSION}

This study reports the masculinization of B. splendens through a discrete immersion of letrozole. Letrozole treatment for $3 \mathrm{~h}$ each on third, fifth and eighth dph produced $100 \%$ males at both 500 and $1000 \mu \mathrm{g} / \mathrm{l}$, whereas it yielded a maximum of $90 \%$ male population at $1000 \mu \mathrm{g} / \mathrm{l}$ when treatment was iven on 

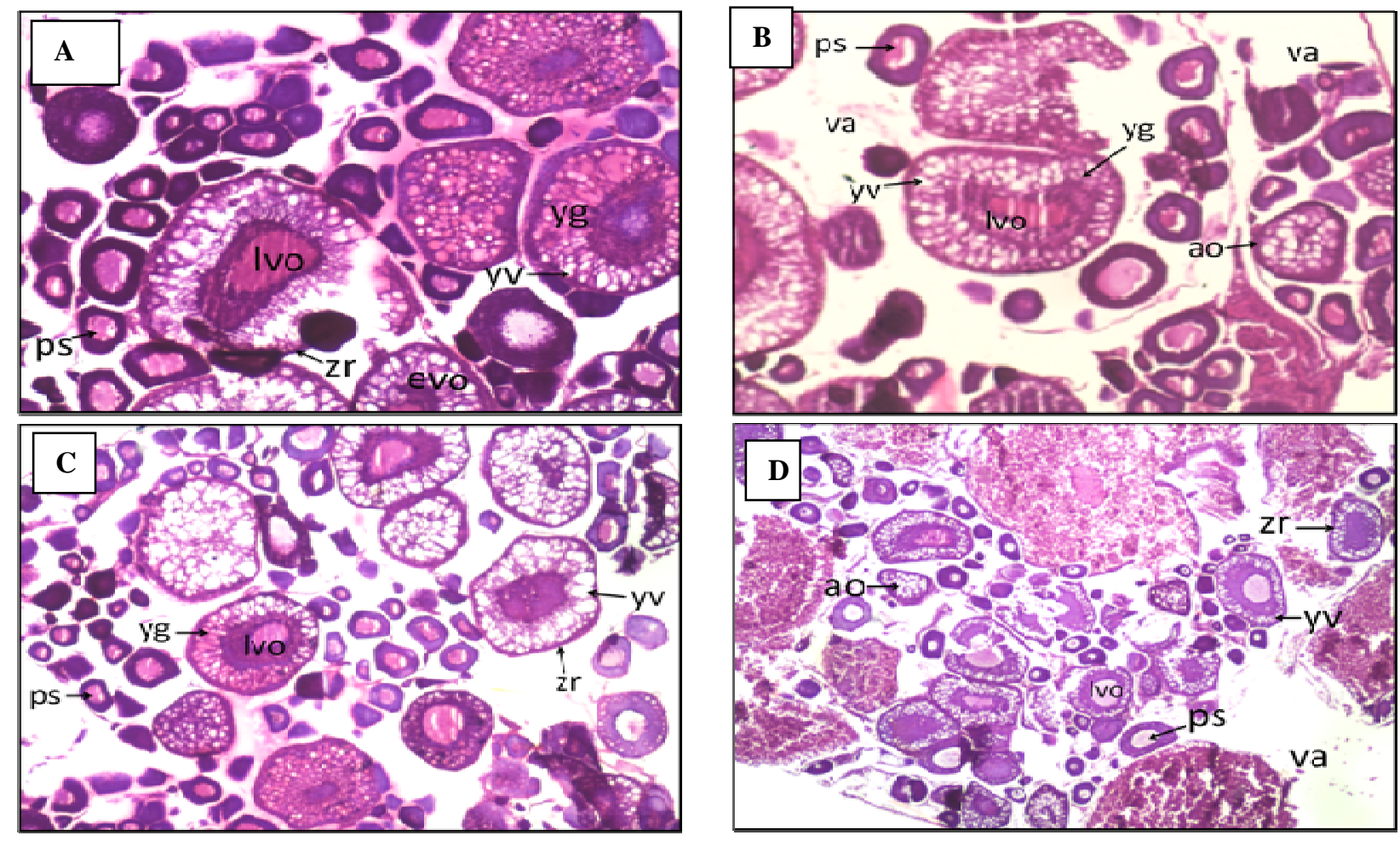

Fig. 2. Photomicrograph of ovary of control fish $(A)$ and $(B)$ fish that received letrozole diet; control fish $(C)$ and $(D)$ fish that received letrozole immersion treatment showing different stages of oogenesis; perinucleolar stage (ps), yolk vesicle $(y v)$, yolk granules (yg), late vitellogenic oocyte (lvo), zona radiata (zr), nucleus ( $n$ ), early vitellogenic oocyte (evo), atretic oocytes (ao), and vacuolar area (va) (H and $E ; 10)$.
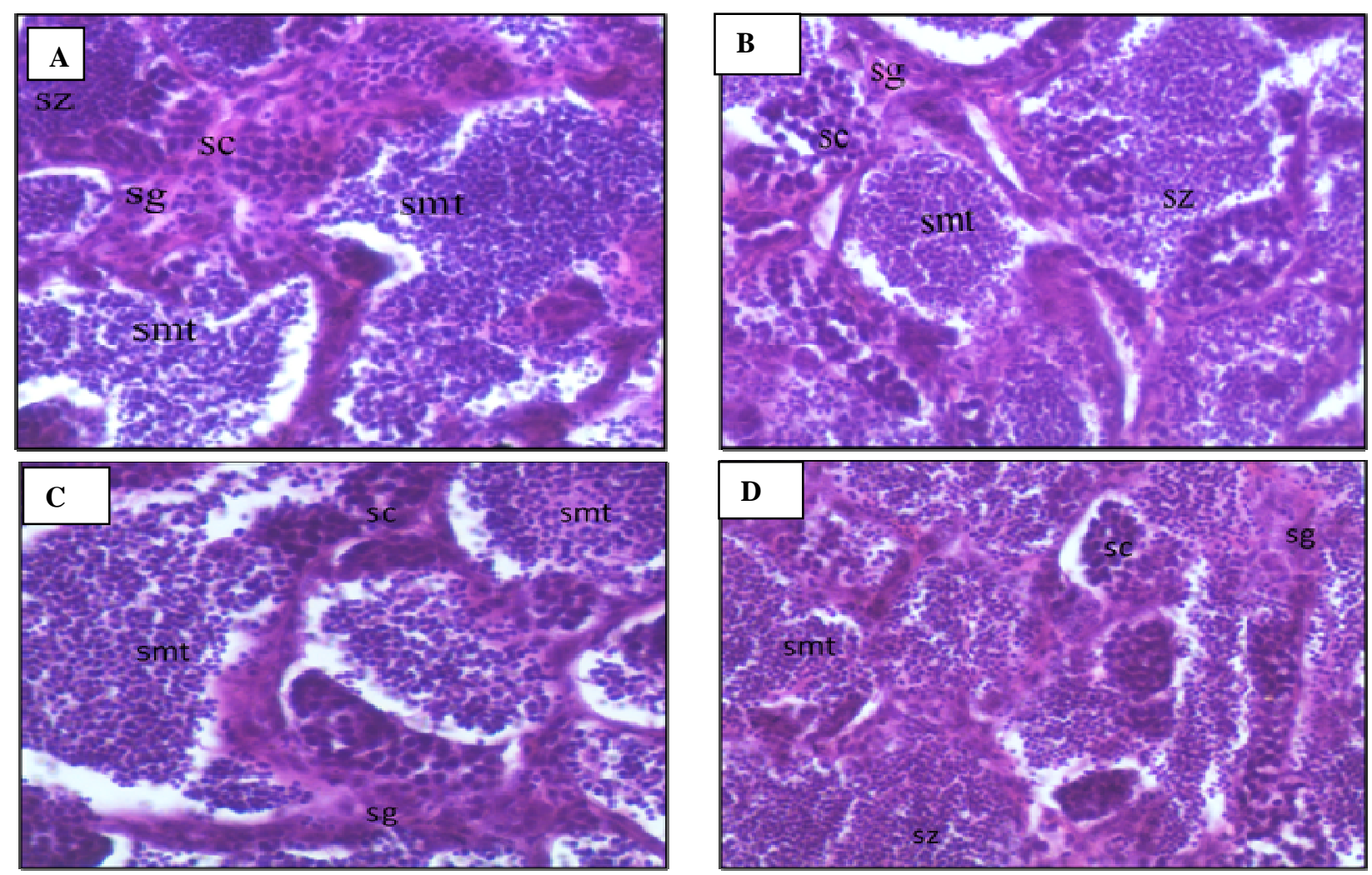

Fig. 3. Photomicrograph of testis of Control $(A)$ and letrozole fed fish $(B)(H \& E ; 40) ;$ control $(C)$ and fish that received immersion treatment of letrozole $(D)$ showing different stages of spermatogonia (sg), spermatocytes (sc), spermatids (smt) and spermatozoa $(s z)(H \& E ; 40)$. 
Table 6. Number of fry stocked and recovered, sex composition and survival of B. splendens given immersion treatment of letrozole (Trial 2).

\begin{tabular}{llllllllll}
\hline & \multicolumn{3}{c}{ Treatment period } & \multicolumn{5}{c}{ Post- treatment period } \\
\hline $\begin{array}{l}\text { Treat- } \\
\text { ment }\end{array}$ & $\begin{array}{l}\text { No. of } \\
\text { fry } \\
\text { (Initial) }\end{array}$ & $\begin{array}{l}\text { No. of fry } \\
\text { (after 8 } \\
\text { days) }\end{array}$ & $\begin{array}{l}\text { Survival } \\
(\%)\end{array}$ & $\begin{array}{l}\text { No. of } \\
\text { fish } \\
\text { recovered }\end{array}$ & Male & Female & $\begin{array}{l}\text { Survival } \\
(\%)\end{array}$ & $\begin{array}{l}\text { Sex } \\
\text { ratio } \\
\text { M:F }\end{array}$ & $\begin{array}{l}\text { Chi- } \\
\text { square } \\
\text { value } \\
\text { against } \\
\mathbf{1 : 1} \text { sex } \\
\text { ratio) }\end{array}$ \\
\hline Control & 40 & 20 & 50 & 11 & $3(27.28)$ & $8(72.72)$ & 55 & $1: 26$ & 2.27 \\
$250 \mu \mathrm{g} / \mathrm{l}$ & 40 & 16 & 40 & 10 & $5(50)$ & $5(50)$ & 62.5 & $1: 1$ & 0 \\
$500 \mu \mathrm{g} / \mathrm{l}$ & 40 & 18 & 45 & 9 & $6(66.66)$ & $3(33.34)$ & 50 & $1: 0.5$ & 1 \\
$750 \mu \mathrm{g} / \mathrm{l}$ & 40 & 15 & 37.5 & 9 & $4(44.44)$ & $5(55.56)$ & 60 & $1: 1.25$ & 0.1 \\
$1000 \mu \mathrm{g} / 1$ & 40 & 17 & 42.5 & 10 & $9(90)$ & $1(10)$ & 58.82 & $1: 0.11$ & $6.4 *$ \\
\hline
\end{tabular}

Sex composition figures given in parentheses are expressed as a percentage of total number of fish. *Statistically significant at 5\% level from the expected 1:1 sex ratio; M: Male, F: Female

Table 7. Results of progeny testing.

\begin{tabular}{|c|c|c|c|c|c|c|c|c|c|}
\hline & & & $\begin{array}{c}\text { No. of } \\
\text { fry } \\
\text { (Initial) }\end{array}$ & $\begin{array}{c}\text { No. of } \\
\text { fish } \\
\text { recovered } \\
\text { and sex }\end{array}$ & $\begin{array}{l}\text { Sur- } \\
\text { vival } \\
(\%)\end{array}$ & Female & Male & $\begin{array}{l}\text { Female } \\
(\%)\end{array}$ & $\begin{array}{c}\text { Sex } \\
\text { ratio } \\
(\mathrm{F}: \mathrm{M})\end{array}$ \\
\hline \multirow{3}{*}{$\begin{array}{l}\text { Letrozole } \\
\text { (oral) }\end{array}$} & Control & & 62 & 24 & 38.70 & $\begin{array}{c}10 \\
(41.66)\end{array}$ & $\begin{array}{c}14 \\
(58.34)\end{array}$ & 41.66 & $1: 1.4$ \\
\hline & \multirow[t]{2}{*}{$150 \mathrm{ppm}$} & Replicate 1 & 69 & 26 & 37.68 & $\begin{array}{c}15 \\
(57.70)\end{array}$ & $\begin{array}{c}11 \\
(42.30)\end{array}$ & 57.70 & $1: 0.73$ \\
\hline & & Replicate 2 & 60 & 23 & 38.33 & $\begin{array}{c}12 \\
(52.18)\end{array}$ & $\begin{array}{c}11 \\
(47.82)\end{array}$ & 52.18 & $1: 0.91$ \\
\hline \multirow{9}{*}{$\begin{array}{l}\text { Letrozole } \\
\text { (immersion) }\end{array}$} & \multirow{3}{*}{ Control } & Replicate 3 & 70 & 28 & 40 & $14(50)$ & $14(50)$ & 50 & $1: 1$ \\
\hline & & Replicate 1 & 90 & 37 & 41.11 & $\begin{array}{c}19 \\
(51.36)\end{array}$ & $\begin{array}{c}18 \\
(48.64)\end{array}$ & 51.36 & 1:0.94 \\
\hline & & Replicate 2 & 75 & 22 & 29.33 & $\begin{array}{c}12 \\
(54.55)\end{array}$ & $\begin{array}{c}10 \\
(45.45)\end{array}$ & 54.55 & $1: 0.83$ \\
\hline & \multirow[t]{3}{*}{$500 \mu \mathrm{g} / \mathrm{l}$} & Replicate 1 & 70 & 29 & 41.42 & $\begin{array}{c}11 \\
(37.93)\end{array}$ & $\begin{array}{c}18 \\
(62.07)\end{array}$ & 37.93 & $1: 1.63$ \\
\hline & & Replicate 2 & 69 & 15 & 21.73 & $8(53.34)$ & $7(46.66)$ & 53.34 & $1: 0.87$ \\
\hline & & Replicate 3 & 80 & 25 & 31.25 & $\begin{array}{c}15 \\
(60.00)\end{array}$ & $\begin{array}{c}10 \\
(40.00)\end{array}$ & 60 & $1: 0.66$ \\
\hline & \multirow[t]{3}{*}{$1000 \mu \mathrm{g} / \mathrm{l}$} & Replicate 1 & 80 & 28 & 35 & $\begin{array}{c}10 \\
(35.71)\end{array}$ & $\begin{array}{c}18 \\
(64.29)\end{array}$ & 35.71 & $1: 1.8$ \\
\hline & & Replicate 2 & 90 & 23 & 25 & $\begin{array}{c}16 \\
(69.56)\end{array}$ & $7(30.44)$ & 69.56 & $1: 0.43$ \\
\hline & & Replicate 3 & 65 & 27 & 41.53 & $\begin{array}{c}18 \\
(66.66)\end{array}$ & $9(33.34)$ & 66.66 & $1: 0.5$ \\
\hline
\end{tabular}

the production of an all-male population of $B$. splendens with letrozole. Kirankumar and Pandian (2002) reported the production of an all-male progeny of Betta through discrete immersion treatment of $17 \alpha-$ MT at doses of 100, 200, 500, 700, 900 and 1,000 $\mu \mathrm{g} / \mathrm{l}$ for a constant duration $(3 \mathrm{~h} /$ day) on second, fifth and eighth dph; $17 \alpha-\mathrm{MT}$ at $900 \mu \mathrm{g} / \mathrm{l}$ produced $98 \%$ males. Balasubramani and Pandian (2008) also demonstrated the masculinization of the B. splendens through immersion treatment of norethindrone (NE) for 3 hours each on the second, fifth and eighth dph and obtained a maximum of $92 \%$ males at $1000 \mu \mathrm{g} / 1$ and observed normal growth and appearance of secondary sexual characteristics. Letrozole induced masculinization in the Lepomis macrochirus through either oral administration or immersion treatment during the sexual differentiation period (Gao et al., 2010). In the present study, moderately high mortality was observed during the first 2-3 days of post-treatment rearing probably because of handling stress and transfer to a new rearing environment. Our study reveals the dietary administration of letrozole at 50, 100, 150 and $200 \mathrm{ppm}$ to 3-4 days old fry for 30, 40 or 50 days did not have any significant effect on the sex ratio. In general, a higher percentage of females were observed in all the treated groups across all the 
treatment duration, including the Control. Jessy and Varghese (1988) obtained $80-91 \%$ males by the oral administration of $17 \alpha-\mathrm{MT}$ at $80-140 \mathrm{ppm}$ for 30 days to 8 day-old-hatchlings in $B$. splendens. Similarly, the oral administration of $17 \alpha-$ MT at doses of $1,2,3$ or 4 $\mathrm{mg} / \mathrm{kg}$ diet for eight weeks induced sex reversal; the higher doses of 3 and $4 \mathrm{mg} / \mathrm{kg}$ resulted in $100 \%$ masculinization in B. splendens (Kipouros et al., 2011). A $100 \%$ male progeny of B. splendens was obtained using NE at $8 \mathrm{mg} / \mathrm{kg}$ diet for 40 days from first day of feeding three times a day (Kavumpurath and Pandian, 1993,1994).

Das et al. (2012) produced $100 \%$ masculinized tilapia (Oreochromis mossambicus) progeny by treating the fry with letrozole at $100-200 \mathrm{mg} / \mathrm{kg}$ diet for 30 days. Similarly, letrozole has been found to induce masculinization in other fishes like Poecilia reticulates, Lepomis macrochiru, Epinephelus akaara, Oryzias latipes (Basavaraja et al., 2012; Gao et al., 2010; Li et al., 2005; Sun et al., 2007). In the present study, the oral administration of letrozole did not induce the production of all male progenies probably because of the less acceptance of the artificial feeds. Several authors point out that the use of artificial diets may give poor survival and low acceptance of feed by fish larvae (Sales and Janssens, 2003; Person et al., 1993; Finn and Kapoor, 2007). This may be the main reason for inability of letrozole to alter the sex ratio when administered orally. High mortality of fry was observed among the treated groups including the control during initial treatment period might have affected the efficacy of letrozole, feeding letrozole only twice a day as against three times daily (Kavumpurath and Pandian, 1994, 1993).

Tail deformities like bent vertebral column and absence of dorsal fins/rudimentary fin were often observed in groups treated with letrozole for 40 and 50 days. Among the groups treated with letrozole for 40 and 50 days, the higher deformities (100 and 87.5\%) were observed at $200 \mathrm{ppm}$ compared to other treated groups, which indicate that as the dose increased the deformity and abnormality also increased. Although the reasons for the observed deformities could not be definitely determined, the same may be attributed to longer treatment period and higher doses of letrozole which might have caused deformity. Salam et al. (2001) observed 7-11\% deformity in ovaries of large mouth bass when treated with diethylstilbestrol at $400 \mathrm{mg} / \mathrm{kg}$ feed. Similarly, Vinod and Basavaraja (2010) observed 7.69, 13.69 and 20\% abnormalities in testis/ovaries by the treatment of diethylstilbestrol at varying doses of 400, 500 and 600 ppm, respectively. Our study also reports the suppression of ovarian growth by letrozole.

Results of the progeny testing of males from letrozole treated (both oral and immersion) indicate that the sex ratio of progenies of each of the males tested did not differ significantly from that of the Control. This shows that all the males carried XY genotype. Chandrashekhara (2011) reported that progeny testing of sex reversed males from $25 \mathrm{ppm}$ letrozole treated group resulted in 30 fish, of which 27 were females and 3 were males and the percentage of females was $90 \%$. The maximum percentage of females $(96.90 \%)$ was found in $100 \mathrm{ppm}$ group (out of 33 fish, 32 were females). The control group had $54.5 \%$ females and $45.5 \%$ males in $L$. reticulates.

The sex reversed male from androgen treatment when mated with normal female produced $100 \%$ monosex female progeny in B. splendens (Kavumpurath and Pandian,1994). Kirankumar and Pandian (2002) obtained $87.25 \%$ female population and only $12.75 \%$ males in B. splendens when sex-reversed males were mated with normal female indicating the possible role of autosomal genes in the sex determination mechanism of this species. Vasanthakumar et al. (2011) observed $88.9 \%$ female progeny in the $C$. Carpio by crossing normal females and males from 30 ppm NE-treated group. Moreover, males of $40 \mathrm{ppm}$ NE treated group when mated with normal female, yielded $79.3,72.2$ and $76.2 \%$ female progeny.

In the present study, the histological examination of ovaries of control fish showed normal stages of oogenesis like perinucleolar stage, oocyte growth, vitellogenesis, etc., whereas the ovary of letrozole -treated fish showed suppressed ovary with degenerating oocytes. Similar results were reported for the letrozole treated and the control guppy L. reticulates. Histological examination of testis showed that there were no significant differences in the testicular development between the control and letrozole treated fish (Chandrashekhara, 2011). Similary, Kirankumar and Pandian (2002) reported that histological examination of the testis of the $17 \alpha$-MT treated male showed histology similar to that of the control male. In the ovary of NE-treated Betta, the no. of vitellogenic oocytes was reduced, while the vacuolar area was increased; in the testis of treated fish, the number of spermatogonia was increased whereas the vacuolar area was reduced (Balasubramani and Pandian, 2008). Vinod and Basavaraja (2010) noticed slightly suppressed testicular development and completely inhibited ovarian development in NE treated groups of common carp $(C$. carpio).

The present study failed to produce a $100 \%$ male population when letrozole was orally administered for varying periods in $B$. splendens but letrozole administration through diet has been found to produce deformities. Studies may be carried out to assess the toxicity of letrozole treatments. More research is required to induce $100 \%$ masculinization through letrozole treatment either by increasing the dosage and/ or duration of administration. 


\section{Conclusion}

It was concluded that the immersion treatment of letrozole was more effective than oral administration in inducing masculinization in B. splendens. The oral treatment of letrozole at the tested doses caused abnormalities and suppressed ovarian development of B. Splendens. The reasons for the observed deformities could not be definitely determined. Hence, this study indicates the scientific direction for future research to assess the toxicity of letrozole treatments in B. Splendens.

\section{ACKNOWLEDGEMENT}

The authors thank Department of Biotechnology, Government of India, New Delhi for financial support (Grant number 8026).

\section{REFERENCES}

Afonso, L.O.B., Wassermann, G.J. and Oloveira, R.T.D.(2001). Sex reversal in Nile tilapia (Oreochromis niloticus) using a nonsteroidal aromatase inhibitor. J. Exp. Zool., 290:177 -181 .

Balasubramani, A. and Pandian, T.J. (2008). Norethindrone ensures masculinization, normal growth and secondary sexual characteristics in the fighting fish, Betta splendens. Curr.Sci., 95(10): 1446-1453.

Basavaraja, N., Chandrashekhara, B.H. and Rather, M.A. (2012). Production of an all-male population of guppy, Poecilia reticulate (Schneider). Curr. Sci., 11:1151-1152.

Chandrashekhara, B.H. (2011). Production of all-male population of Lebistes reticulates (Robert John Lechmn,1866) through the application of aromatase inhibitor, MFSc thesis, Karnataka Veterinary, Animal and Fisheries Sciences University, Bidar.

Das, R., Rather, M.A., Basavaraja, N., Sharma, R. And Udit, U.K. (2012). Effect of nonsteroidal aromatase inhibitor on sex reversal of Oreochromis mossambicus (Peters, 1852). Isr. J. Aquacult. - Bamidgeh, 64: 1-6.

Fenske, M. and Segner, H. (2004). Aromatase modulation alters gonadal differentiation in developing zebra fish (Danio rerio). Aquat. Toxico., 67:105-126.

Finn, R.N. and Kapoor, B.G. (2007). Fish Larval Physiology, Science Publishers, New Hampshire.

Gao, Z.X., Wang, H.P., Wallat, G., Yao, H., Rapp, D., O’bryant, P., MacDonald and Wang, W.M. (2010). Effects of a nonsteroidal aromatase inhibitor on gonadal differentiation of bluegill sunfish, Lepomis macrochirus. Aquacult. Res., 41: 1282 .

Gray, P. (1964). Handbook of Basic Microtechniques. McGraw -Hill Book Company. 3rd ed, New York.

Guerrero, R.D. (1975). Use of androgens for the production of all-male Tilapia aurea. Transactions of the American Fisheries society., 104:342-348.

Howell, A., Cuzick, J., Baum, M., Buzdar, A., Dowsett, M., Forbes, J.F., Hoctin-Boes, G., Houghton, J., Locker, G.Y. and Tobias, J.S. (2005). Results of the ATAC (arimidex, tamoxifen, alone or in combination) trial after completion of 5 years' adjuvant treatment for breast cancer. Lancet., 365: 60-62.

Jessy, D. and Varghese, T.J. (1988). Hormonal sex control in Betta splendens (Regan) and Xiphophorus helleri (Heckel), Paper presented to First Indian Fisheries Forum, Asian
Fisheries Society, Indian Branch, Mangalore, India, pp 26-31.

Kavumpurath, S. and Pandian, T.J. (1993). Determination of labile period and critical dose for sex reversal by oral administration of estrogens in Betta splendens Regan. Indian. J. Exp. Biol., 31:16-20.

Kavumpurath, S. and Pandian, T.J. (1994). Masculinization of fighting fish, Betta splendens Regan, using synthetic or natural androgens. Aquacutlt Fish Manage., 25: 373-381.

Kipouros, K., Paschos, I., Gouva, E., Ergolavou, A.and Perdikaris, C. (2011). Masculinization of the ornamental Siamese fighting fish with oral hormonal administration. Sci. Asia., 37:277-280.

Kirankumar, S. and Pandian, T.J. (2002). Effect on growth and reproduction of hormone immersed and masculinized fighting fish Betta splendens. J. Exp. Zool., 293: 606-616.

Kitano, T., Takamune, K., Nagahama, Y. and Abe, S.I. (2000). Aromatase inhibitor and 17alpha-methyltestosterone cause sex-reversal from genetical females to phenotypic males and suppression of P450 aromatase gene expression in Japanese flounder (Paralichthys olivaceus). Mol. Reprod. Dev., 56: 1-5.

Kwon, J.Y., Haghpanah, V., Kogson-Hurtado, L.M., McAn drew, B.J. and Penman, D.J. (2000). Masculinization of genetic female Nile tilapia (Oreochromi sniloticus) by dietary administration of an aromatase inhibitor during sexual differentiation.J. Exp. Zool., 287:46-53.

Li, G.L., Liu, X.C. and Lin, H.R. (2005). Aromatase inhibitor letrozole induces sex inversion in the protogynous red spotted grouper (Epinephelus akaara). Acta. Physiol. Sin., 57: 473-479.

Pandian, T.J. and Sheela, S.G. (1995). Hormonal induction of sex reversal in fish. Aquaculture, 138 :1-22.

Person, L.R.J., Alexandre, J.C., Thebaud, L.andMugnier, C. (1993).Marine fish larvae feeding: Formulated diets or live prey. J. World. Aquacult. Soc., 24 (2): 211-224.

Piferrer, F., Zanuy, S., Carrillo, M., Solar, I.I., Devkubm, R. H. and Donaldson, E.M. (1994). Brief treatment with an aromatase inhibitor during sex differentiation causes chromosomallyfemale salmon to develop as normal, functional males. J.Exp. Zool., 270:255-262.

Salam, A., Ai-Ablani, Ronald. P. and Phelps (2001). Induction of feminization in large mouth bass (Micropterus salmoides) by oral administration of estradiol-17 $\beta$ or diethylstilbestrol and associated Pathological changes. J. Aquacult. Trop., 16 (2):185-195.

Sales, J. and Janssen, G.P.J. (2003). Nutrient requirements of ornamental fish. Aquat. Liv. Resour., 16: 533-540.

Steele, R.E., Mellor, L.B., Sawyer, W.K., Wasvary, J.M. and Browne, L.J. (1987). In vitro and in vivo studies demonstrating potent and selective estrogen inhibition by the non-steroidal aromatase inhibitor CGS16949. Steroids., 50: 147-161.

Sun, L.W., Zha, J.M., Spear, P.A. and Wang, Z.J.(2007). Toxicity of the aromatase inhibitor letrozole to Japanese medaka (Oryzias latipes) eggs, larvae and breeding adults. Comp. Bioche. Physiol., 145: 533-541.

Vasanthakumar, A., Basavaraja, N., Manjappa, N. and Vinod, B.H. (2011). Manipulation of sex and progeny testing in common carp, Cyprinus carpio(Linn.). J. Aquacult. Trop., 26:63-81.

Vinod, B.H. and Basavaraja, N. (2010). Effect of diethylstilbestrol and norethindrone on sex ratio and body indices of common Carp, Cyprinus carpio (Linn.). Asian Fish Sci., 23: 100-115. 